$$
\text { Fyson, R \& Fox, L (2014) }
$$

Inclusion or Outcomes? Tensions in the involvement of people with learning disabilities in strategic planning

Disability \& Society: 29 (2) 239-254

DOI: $10.1080 / 09687599.2013 .776491$

http://www.tandfonline.com/doi/abs/10.1080/09687599.2013.776491 


\title{
Inclusion or outcomes? Tensions in the involvement of people with learning disabilities in strategic planning
}

\author{
Abstract \\ Social inclusion is a key principle which underpins the provision of services for \\ people with learning disabilities in England. Learning Disability Partnership Boards, \\ which are responsible for local strategic planning of learning disability services, hold \\ a particular role in promoting inclusion since they are required both to operate \\ inclusively and to achieve inclusive outcomes. This study sought to explore the extent \\ to which these ambitions for inclusion were being achieved. It consisted of three \\ phases: a scoping exercise to elicit the views of key stakeholders; a postal survey of \\ Partnership Boards (response rate 51\%); and semi-structured interviews with \\ Partnership Boards members in six local authorities. Findings suggest that Partnership \\ Boards are struggling to fulfil their dual role, with tensions emerging between the \\ desire to operate in fully inclusive ways and the ability to affect strategic change \\ within local services.
}

\section{Key words}

Inclusion; learning disability; Learning Disability Partnership Boards; strategic planning; strategic change 
A note on terminology: the terms 'self-advocate', 'service user' and 'people with learning disabilities' are each used in this article to denote specific identities. 'Selfadvocate' refers to those people with learning disabilities who have joined a selfadvocacy group with the intention of speaking up about their needs. 'Service user' refers to people with learning disabilities who are eligible for publicly funded social care services. 'People with learning disabilities' refers to a wider group of people who may or may not be members of self-advocacy groups and/or eligible for publicly funded social care services.

\section{Introduction}

'Inclusion' is a key principle which, together with 'rights', 'independence' and 'choice', underpins English learning disability services. These principles were set out in the Valuing People white paper (Department of Health, 2001), in which the concept of inclusion is introduced in the following terms:

Inclusion: Being part of the mainstream is something most of us take for granted. We go to work, look after our families, visit our GP, use transport, go to the swimming pool or cinema. Inclusion means enabling people with learning disabilities to do those ordinary things, make use of mainstream services and be fully included in the local community. (ibid, p. 24)

This pursuit of social inclusion is not new: for decades English Government policies have explicitly promoted inclusion, both geographically and socially, for people with learning disabilities (Department of Health 1971 \& 2001). Despite this, many people with learning disabilities continue to struggle to achieve inclusion in mainstream society (Hamlin \& Oakes, 2008; Hall, 2004; Forrester-Jones et al, 2006). People with learning disabilities have themselves identified a number of ongoing barriers to social inclusion, including the location of their homes in relation to local amenities; lack of necessary knowledge and skills; and attitudes towards learning disability amongst members of the local community (Abbott \& McConkey, 2006). Social exclusion is compounded by economic marginalisation: few people with learning disabilities are in paid employment (Hall, 2004; Department of Health 2001) and those who are typically work for five hours per week or less (Beyer et al, 2004). People with 
profound and multiple learning disabilities often only achieve community presence rather than active participation and inclusion (Clement \& Bigby, 2009).

In this context, it was a bold step for Valuing People to apply the principles of inclusion not only to services for people with learning disabilities, but also to the way in which it was to be implemented. This meant that the concept of 'partnership' in learning disability services was extended beyond the established partnerships between statutory health and social care agencies, to embrace partnerships with service users and family carers:

Inclusion: people with learning disabilities and their families will be given the opportunity to be involved in local partnerships. (Department of Health, 2001, p. 106)

People with learning disabilities and family carers were written into the fabric of Valuing People implementation through their inclusion in new strategic bodies. Nationally, this meant membership of the Learning Disability Taskforce set up to provide England-wide oversight of the Valuing People programme. Locally, this meant membership of the Learning Disability Partnership Boards which every English local authority with a social services function was required to establish.

Partnership Boards had to include not only at least two people with learning disabilities and two family carers, but also representatives from a wide range of stakeholder groups, including commissioning agencies and service providers from across the statutory, independent and voluntary sectors. To give a sense of their intended scope, Valuing People provided the following list of suggested participants:

Membership should include senior representatives from social services, health bodies (health authorities, Primary Care Trusts), education, housing, community development, leisure, independent providers, and the employment service. Representatives of people with learning disabilities and carers must be enabled to take part as full members (Department of Health, 2001, p. 108) 
The role of Partnership Boards was explained as being to 'take responsibility for local delivery of the White Paper' (Department of Health, 2001, p.130). Initial guidance (Department of Health, 2001a) emphasised that Boards were expected to produce a range of local strategic plans - for example on housing, employment, person-centred planning and hospital closure - but said little about the mechanisms by which Boards might ensure that these plans were implemented. Beyond this, Valuing People provided minimal detail regarding how Partnership Boards should operate, except for the exhortation that people with learning disabilities and family carers should 'make a real contribution' and that Boards should reflect 'the cultural diversity of the local community' (Department of Health, 2001, p.108); further guidance reiterated that 'the Government expects Partnership Boards to be the place where local decisions are made' (Department of Health, 2002, p.16). From the outset, then, Partnership Boards have been construed by policy-makers as both important centres for the enactment of inclusive practices and as key strategic bodies.

Since their inception, the progress of Partnership Boards has been monitored -albeit somewhat erratically - by the Learning Disability Taskforce. Their first report highlighted difficulties which have continued to be apparent, noting that:

Partnership Boards have had to do things very quickly so they can keep up with demands from the Government for new policies and plans. That has made it very difficult to really include people with learning disabilities in their work. The balance between doing things quickly and doing things well has not been right. (Learning Disability Taskforce, 2003, p.60)

Subsequent reports (Learning Disability Taskforce, 2004, $2005 \&$ 2007) do not comment directly on the success or otherwise of Partnership Boards in fulfilling their inclusive or strategic functions, but do repeatedly mention Partnership Boards in ways which identify them as the key means of ensuring local implementation of strategic priorities.

Given this reliance on Partnership Boards it might be supposed that there was strong evidence of their efficacy in relation to either or both of their dual roles. This is not the case. The first study of Partnership Boards, undertaken during the year they were 
created, noted difficulties with establishing Boards within the required timeframe and with meeting centrally-imposed deadlines for developing local strategy documents (Whitworth, 2002). This study did not explore whether the resulting strategies were implemented effectively, but did note tensions between the requirement upon Partnership Boards to actively involve people with learning disabilities and the necessity of making rapid decisions about complex issues. Several studies involving researchers with a learning disability have explored whether Partnership Boards operate in ways which are accessible and inclusive. These suggest some improvement to inclusive practices over time: practical measures have commonly been introduced, including documents in accessible formats with easy words and pictures; banning the use of jargon; using 'traffic light cards' to enable individuals to slow the pace of discussion; and using 'break out groups' to allow discussion to take place within smaller groups (Speaking Up, 2007; Fyson, McBride \& Myers, 2004; Scott, 2003). However, these studies say little about whether Boards were achieving wider strategic outcomes.

Other studies have echoed the early concerns raised by Whitworth (2002) and the Learning Disability Taskforce (2003), as well as voicing a number of new concerns. Prominent amongst the difficulties repeatedly identified has been the question of whether Partnership Boards members are truly representative of wider communities of people with learning disabilities and family carers (Mencap, 2003; Fyson, McBride \& Myers, 2004; Fyson \& Ward, 2004). One study characterised people with learning disabilities who were members of Partnership Boards as typically being 'relatively young, white men with good verbal skills' (Fyson, McBride \& Myers, 2004, p. 30) and noted that self-advocates who became members of Partnership Boards were not always current users of learning disability services. Other research has revealed a failure to include all people with learning disabilities within Partnership Board processes, with people with profound and multiple learning disabilities (Mencap, 2004) and people from black and minority ethnic communities (Hatton, 2004) found to often be without representation. 
More recently, there have been two detailed studies of interactions in forums intended to enable people with learning disabilities to participate in policy making. The first, by Redley and Weinberg (2007) describes itself as a 'detailed ethnography' and involved discourse and conversation analysis techniques being applied to videorecordings of a local 'parliament' for people with learning disabilities. Their findings demonstrate the difficulties which many people with learning disabilities experience when asked to present themselves in such a forum, and highlight what the authors term 'interactional impediments' to full inclusion in such processes. The second, by Riddington et al (2008) examined interactions at Partnership Boards in three local authorities. Their findings suggest that, although physically present, people with learning disabilities were typically passive in these environments, making few spontaneous interjections. Meetings were described as "taken up with topics that raised members' awareness of forthcoming plans or initiatives" (ibid, p. 657) and characterised as information exchanges rather than as places of either discussion or decision-making.

It is notable that previous studies focussed largely on inclusion as a process which occurs within Partnership Boards. Less, if any, work has examined the effectiveness of Partnership Boards as strategic bodies able to influence policy outcomes. This is significant, not least because the ultimate purpose of Partnership Boards is the implementation of Valuing People principles which seek social inclusion for all people with learning disabilities. Furthermore, Partnership Boards are the first, and to date only, nationwide attempt to involve people with learning disabilities in strategic planning - and the validity of this as a means of achieving inclusive outcomes remains to be proven. This study, funded by Mencap, therefore sought to both build on and expand existing knowledge by examining both inclusive practices within Partnership Boards and the outcomes of Board processes in terms of directing strategic changes which would support social inclusion.

\section{Methodology}

Mixed methods were used across three phases of data collection and analysis. This methodological mix enabled the findings to be more robustly generalisable than a 
stand-alone small-scale qualitative study and more richly detailed than the abstraction of a purely statistical study. Ethical approval was obtained prior to the start of data collection, through The University of Nottingham's research governance process.

The first phase was a scoping exercise, engaging with key stakeholders to develop the questionnaire used in phase two. It involved telephone interviews with Valuing People Support Team (VPST) officers in the nine English regional implementation teams and an accessible questionnaire being sent to 120 self-advocacy organisations.

The second phase involved a postal survey of all Learning Disability Partnership Boards $(n=146$; response rate $=51 \%)$. This used open and closed questions to generate both quantitative and qualitative data about both processes and outcomes. On the 'process' side, respondents were asked who attended meetings, who the Board reported to and how decisions were made. On the 'outcomes' side, the survey asked what influence Partnership Boards had on local strategic decisions; what strategic targets had been set, whether these had been achieved, and the barriers respondents perceived to achieving such targets.

The final phase involved semi-structured interviews $(n=18)$ with members of Partnership Boards in six local authorities. These elicited direct accounts of participation in Partnership Board meetings, including respondents' experiences of inclusive practices and the value of participation in terms of securing desired outcomes. Interviewees included people with learning disabilities, family carers, senior managers from statutory social care services, local councillors and representatives from other organisations who attending meetings.

Quantitative data was collated using SPSS to provide descriptive statistics; correlations between key variables were analysed, but no statistically significant links were identified. All figures given in tables and text are presented as percentages and have been rounded up or down to the nearest whole number. A thematic analysis of content was undertaken using qualitative data from both the survey and interviews. 
This involved an iterative process in which each author separately coded data into emergent themes before coming together to compare coding categories and agree a shared set of identified themes which form the basis of the findings which follow.

\section{Initial scopings}

Responses to the scoping exercise revealed no obvious regional trends in how Partnership Board operated although VPST advisors indicated that adjacent local authorities with similar socio-demographic profiles had sometimes achieved different degrees of inclusion within their Partnership Boards.

The most striking factor about responses from self-advocacy groups was the extent to which they focussed on matters of process within Board meetings rather than on outcomes in terms of change to local services. Self-advocates repeatedly highlighted the failure of Boards to involve certain groups, particularly people from black and minority ethnic communities; people with profound and multiple learning disabilities or complex needs; and people who did not use specialist learning disability services. They also raised questions regarding how individuals came to be members of Partnership Boards, the support available to enable participation, and how those attending meetings consulted (or failed to consult) other local people with learning disabilities. Several self-advocates also expressed concern about whether people with learning disabilities were being listened to - both literally at meetings and in terms of having an impact on decisions about local service provision.

\section{Inclusion in the context of Partnership Board meetings}

The survey found that Partnership Boards typically involve significant numbers of people, with over half (56\%) of respondents indicating meetings of 21-30 or 30+ people. All Partnership Boards included people with learning disabilities and family carers amongst their membership. Within this, the number of people with a learning disabilities ranged from one or two (10\% of Boards) through to seven or more (22\% of Boards). No correlation was found between the overall number of people attending 
meetings and the number of people with learning disabilities who attended. It was, however, noted that people with learning disabilities were always in a minority.

The survey supported concerns raised by the scoping exercise about the diversity - or 'representativeness' - of learning disabled and carer members of Partnership Boards. More men than women with learning disabilities attended meetings; people with learning disabilities aged under 30 were more likely to attend than those aged over 60; and attendance by people with learning disabilities from minority ethnic communities was a regular occurrence at only $30 \%$ of Boards. Similarly, carers were more likely to be female than male, and only $17 \%$ of Boards saw regular attendance of carers from minority ethnic communities. This suggests that, even though people with learning disabilities and family carers are in a general sense included in Partnership Boards, some groups are better represented - and therefore 'more included' - than others.

Physical presence at meetings, however, does not guarantee meaningful inclusion: the challenge of attaining active inclusion and participation was therefore a matter of concern to many interviewees. One Board member with a learning disability described how "There can be problems because people jump in - they don't listen to us", whilst a carer complained that "The Board is top heavy with people from the Local Authority".

Most Partnership Boards were eager to be seen to include people with learning disabilities and the vast majority ( $82 \%)$ were co-chaired by someone with a learning disability. However, interviewees reported that the role of a learning disabled co-chair was largely ceremonial and the non-disabled co-chair remained in control of calling people to speak and overseeing voting processes (where they occurred). The Chair's role in shaping debate was important because many Boards lacked any formal decision-making processes: almost half (47\%) reported that decisions were based upon reaching 'consensus agreement'. This approach may have the potential to be a good model of inclusion, but in practice it appeared that the views of the more powerful tended to hold sway. As the following quotes demonstrate, those with 
greater power were more sanguine about the consequences of this dynamic than those with less power:

Views are considered in principle - but there have to be executive decisions this comes after discussion, the principles are fully adhered to but with a Partnership Board you just haven't the time to go into everything, because you would be there for hours. [Chair \& Manager of statutory services]

I think this has probably happened in other places as well, but sub groups are disbanded by LAs (local authorities) because they haven't time to chair it or they have found a different way of doing the work without involving the subgroup, but that's not in discussion with the sub-group, it's a fait accompli.

[Voluntary sector representative]

There were arguments about how money was spent, but people from the Local Authority fobbed us off; they said 'your points have been noted'. [Carer representative]

The carers talk a lot and sometimes they do take over about things that they want sorting out. [Learning disabled Board member]

A small minority of Boards (7\%) reported that they did not make any formal decisions and instead simply minuted discussions which had taken place. Again, this approach could have the benefit of ensuring that conflicting views are documented rather than glossed over, but it implies that Partnership Boards are more akin to consultative forums than to strategic planning bodies. A voluntary sector representative summarised the situation as: "The Partnership Board means that they - statutory services - are more willing to consult with people. I wouldn't say that they [people with learning disabilities] are being listened to, though".

As noted earlier, the original remit of Partnership Boards required the inclusion of people with learning disabilities, family carers and representatives from a variety of specialist and generic, statutory and non-statutory agencies. Table 1 shows that this ambition has only partially been met. 
Table 1: Organisational, professional and special interest attendance at Partnership Boards

\begin{tabular}{lccc} 
& $\begin{array}{l}\text { Never } \\
\text { attend } \\
\text { meetings } \\
\%\end{array}$ & $\begin{array}{l}\text { Occasionally } \\
\text { attend } \\
\text { meetings } \\
\%\end{array}$ & $\begin{array}{l}\text { Regularly } \\
\text { attend } \\
\text { meetings } \\
\%\end{array}$ \\
\hline $\begin{array}{l}\text { Specialist disability agencies and } \\
\text { professionals }\end{array}$ & 0 & 1 & 99 \\
Social services - senior manager & 4 & 22 & 74 \\
Primary Care Trust & 1 & 10 & 89 \\
Independent sector service provider & 35 & 38 & 27 \\
Frontline social worker & 54 & 24 & 22 \\
Clinical psychology & 43 & 30 & 27 \\
Frontline carer/support worker & & & 27
\end{tabular}

Generic agencies

Housing Department (Local Authority) $\quad 22 \quad 43 \quad 35$

$\begin{array}{llll}\text { Supporting People team } & 26 & 46 & 28\end{array}$

$\begin{array}{llll}\text { Leisure services (Local Authority) } & 43 & 38 & 19\end{array}$

$\begin{array}{llll}\text { Adult Education } & 19 & 48 & 33\end{array}$

$\begin{array}{llll}\text { Learning \& Skills Partnership } & 34 & 40 & 26\end{array}$

$\begin{array}{llll}\text { Job Centre Plus } & 61 & 23 & 16\end{array}$

$\begin{array}{llll}\text { Supported employment services } & 22 & 31 & 47\end{array}$

$\begin{array}{lllll}\text { Children's services/transitions worker } & 12 & 41 & 47\end{array}$

Special interest groups

Nominated 'champion' for ethnic minority service users

Nominated 'champion' for people with profound and multiple disabilities

Nominated 'champion' for adult protection issues 
The involvement of 'nominated champions' to represent the interests of particular groups was disappointing. Only $32 \%$ of Boards were regularly attended by a nominated champion for black and ethnic minority services users, a number which fell to $30 \%$ with regard to champions for people with profound and multiple disabilities and to a mere $16 \%$ with regard to a nominated champion for adult safeguarding issues. Almost half of Boards did not include nominated champions for any of these groups.

Ethnicity, profound and multiple learning disability and adult safeguarding are very different issues, but all concern individuals who are likely to be among the most vulnerable and marginalised within the learning disability community. Whilst the existence of 'nominated champions' is only a proxy indicator of whether the needs of these groups are being considered by Partnership Boards, these findings suggest a potential lack of engagement with issues of inclusion for multiply disadvantaged groups. Whilst direct inclusion - particularly for people with profound and multiple disabilities - may not be practicable, it remains imperative that specific and effective representation of their interests is achieved.

Table 1 also shows that involvement of non-specialist agencies was sporadic. Providers of specialist services for people with learning disabilities, including social services (99\%), health trusts (74\%) and the independent sector (89\%) regularly attended Partnership Board meetings. By contrast, levels of attendance stood at below half for all generic agencies (housing 35\%, leisure 19\%, adult education 33\%, etc). This is problematic because it suggests that many non-specialist public services are not engaging in inclusive policy processes. And it is therefore questionable whether they are likely to actively pursue policies to enable the inclusion of people with learning disabilities in wider contexts.

\section{Inclusive outcomes from Partnership Board activities?}

Whilst the constitution of, and processes within, Partnership Boards are important for the inclusion of people with learning disabilities in strategic planning the ultimate purpose of Boards is to oversee the implementation of strategies for ensuring the inclusion of people with learning disabilities in their local communities. The present study therefore used evidence of outcomes - including public accountability; 
influence over policy decisions; and changes to the provision of services - as proxy indicators for the achievement of wider goals of inclusion.

Despite being publicly funded bodies with an inclusionary remit, Partnership Boards did not fare well on measures of public accountability. Only half (50\%) of Boards held meetings in public and only one third (32\%) produced a publicly available annual report. It was not surprising therefore to find interviewees echoing the views of self advocates during the scoping exercise and expressing unease that public knowledge of Partnership Boards was limited or non-existent.

The learning disability community is well represented, but the neighbourhood community probably doesn't know a lot about the Partnership Board.

(Manager, Voluntary sector)

I have never heard the Partnership Board mentioned in a decision making process elsewhere. (Nominated Champion)

This limited public and political profile was echoed in the limited influence of Partnership Boards over local learning disability strategy. Despite being heralded as 'strategic bodies' the evidence from this study suggests that many Partnership Boards had little or no influence over key decisions about learning disability services.

As table 2 shows, many Boards were not consulted by statutory agencies about major strategic decisions. For example, almost half (49\%) had no involvement when cuts were made to Local Authority learning disability budgets; nearly two-thirds (64\%) had no involvement when cuts were made to health budgets; and one third (34\%) had no involvement in changes to services' eligibility criteria. Levels of consultation were higher for operational decisions, such as the closure or merger of existing services and the development of new services, but even on these issues only a tiny proportion of Boards were the final arbiter (ranging from $0 \%$ to $5 \%$ ). The only sphere in which Boards appeared to play a major role was the allocation of Learning Disability Development Fund (LDDF) monies: these relatively small amounts of money were linked to the Valuing People programme and guidance specifies that it is "for local learning disability partnership boards to determine its allocation" (Department of Health, 2007, p.38). Despite this direct guidance, it was notable that only $70 \%$ of 
Boards reported having the final say over how to spend LDDF monies and $4 \%$ reported having no involvement whatsoever.

$\underline{\text { Table 2: Partnership Board involvement in strategic decisions }}$

$\begin{array}{lll}\begin{array}{l}\text { No formal } \\ \text { involvement } \\ \text { in this matter }\end{array} & \begin{array}{l}\text { Consulted, } \\ \text { but decision } \\ \text { made } \\ \text { elsewhere }\end{array} & \begin{array}{l}\text { Has final say } \\ \text { in these } \\ \text { decisions }\end{array} \\ \% & \%\end{array}$

Agreeing overall health

68

32

0 expenditure on intellectual disability services

Agreeing overall Local

Authority expenditure on intellectual disability services

Cuts to Local Authority

intellectual disability budget

Cuts to health intellectual

disability budget

Allocation of Learning

Disability Development Fund monies

Changes to eligibility criteria

for services

Closure or merger of day services

Development of new day 
So, if Partnership Boards are at best marginal to and at worst excluded from strategic decision making, what are their achievements in promoting social inclusion? When asked to identify something positive that their Board had achieved in the past year, around a quarter of survey respondents mentioned something related purely to the organisation or process of Board meetings, such as:

A person with learning disabilities now Co-Chairs the Board

The role and membership of the Board was reviewed

The Partnership Board has worked hard to promote inclusion and now allows observers

We have changed the way we meet to include more people with a learning disability

Minutes provided in an accessible format

Whilst these examples will have made meetings more inclusive, they are unlikely to promote inclusion in its broader sense.

Other respondents gave examples of achievement which were more outcomefocussed, but nevertheless fell short of having a measurable impact on local service provision. Typical examples were of Boards which cited their achievement as having 'developed plans', 'undertaken reviews' or 'promoted values', but without noting further outcomes, for example:

Learning disability housing strategy

Developed an employment action plan

LDDF [Learning Disability Development Fund] used to promote Valuing People objectives

Only a small minority of respondents provided specific examples Partnership Board achievements. These ranged from frankly minor feats, such as producing ' $a$ multifaith calendar' through to important developments which had clearly promoted social inclusion: 
As a result of a 'Health Day' some good progress made with health targets, i.e. GP registration increased from $70 \%$ to $98 \%$

Agreed a housing \& support strategy that has led to 46 new tenancies this year

Employed 3 new advocacy workers - including one for BME [black \& minority ethnic] groups and one for parents with learning disabilities

Respondents were also asked for examples of targets which their Board had set for the coming year. As with achievements, many targets were inward-looking, such as 'Revisit constitution of Board and roles of reps' or 'Review terms of reference'. Only a minority of Partnership Boards were setting clear targets, with measurable outcomes, for activities which would promote social inclusion. And, as table 3 shows, in some areas of policy and service delivery no Boards reported having measurable targets.

Whilst targets do not of themselves guarantee outcomes, they do enable progress towards agreed goals to be measured. The lack of measurable targets proves only that the strategic effectiveness of many Partnership Boards cannot accurately be judged. However, when considered in conjunction with other data from this study, in particular the inward-looking nature of many targets and reports from Partnership Board members of the 'talking shop' nature of meetings, it would not be unreasonable to infer that many Boards are failing to fulfil the strategic element of their role effectively.

Table 3: Examples of targets set by Partnership Boards

\begin{tabular}{|l|l|l|}
\hline $\begin{array}{l}\text { Area of } \\
\text { service }\end{array}$ & Measurable targets & Unmeasurable targets \\
\hline Advocacy & $\begin{array}{l}\text { Provision of advocacy } \\
\text { services }-850 \text { hours of self } \\
\text { advocacy; 40 carers } \\
\text { supported; } 2 \text { peer advocates; } \\
80 \text { people benefiting from } \\
\text { task-based advocacy }\end{array}$ & Increase advocacy \\
\hline Health & $*$ & $\begin{array}{l}\text { Work with hospitals to improve } \\
\text { access for people with learning }\end{array}$ \\
\hline
\end{tabular}




\begin{tabular}{|c|c|c|}
\hline & & $\begin{array}{l}\text { disabilities } \\
\text { Improved experiences of primary } \\
\text { health }\end{array}$ \\
\hline Employment & $\begin{array}{l}12 \text { people with LD employed } \\
\text { in Local Authority }\end{array}$ & $\begin{array}{l}\text { Better pathways to employment } \\
\text { Getting more people into work } \\
\text { Increase the number of people in } \\
\text { paid employment and voluntary or } \\
\text { permitted work }\end{array}$ \\
\hline Day services & $*$ & $\begin{array}{l}\text { More flexible daytime activities } \\
\text { Modernisation of day services } \\
\text { More modernised day services and } \\
\text { increased day opportunities for } \\
\text { people with learning difficulties }\end{array}$ \\
\hline $\begin{array}{l}\text { Support for } \\
\text { carers }\end{array}$ & $\begin{array}{l}\text { More carers are offered a } \\
\text { carers assessment and are } \\
\text { supported through a flexible } \\
\text { carers short break (target for } \\
80 \text { assessments \& } 80 \text { carers } \\
\text { supported by short breaks in } \\
\text { each of next } 3 \text { financial } \\
\text { years) }\end{array}$ & $\begin{array}{l}\text { Explore opportunities to engage } \\
\text { with users \& carers from ethnic } \\
\text { minority communities }\end{array}$ \\
\hline Housing & $\begin{array}{l}\text { To have } 20 \text { additional } \\
\text { tenancies for people with a } \\
\text { learning disability living in } \\
\text { their community } \\
\text { Development of standards } \\
\text { approved by the Board in the } \\
\text { commissioning of new } \\
\text { services e.g. supported living }\end{array}$ & $\begin{array}{l}\text { Increase in numbers of people living } \\
\text { in accommodation in the } \\
\text { community as opposed to } \\
\text { residential care } \\
\text { Improving housing options } \\
\text { Reduce the numbers of people with } \\
\text { learning disabilities living in } \\
\text { residential care }\end{array}$ \\
\hline $\begin{array}{l}\text { Direct } \\
\text { payments }\end{array}$ & $\begin{array}{l}\text { Increase in take up of direct } \\
\text { payments to minimum of } 39 \\
\text { within this financial year }\end{array}$ & $\begin{array}{l}\text { Percentage of people receiving } \\
\text { direct payments }\end{array}$ \\
\hline $\begin{array}{l}\text { Person } \\
\text { centred } \\
\text { planning }\end{array}$ & $\begin{array}{l}100 \text { person centred plans } \\
\text { 12-15 new Circles of Support } \\
\text { for older people with } \\
\text { learning disabilities }\end{array}$ & $\begin{array}{l}\text { Increase in number of people in } \\
\text { receipt of Person Centred Plan }\end{array}$ \\
\hline Other & $\begin{array}{l}\text { Get a 'Changing Places' } \\
\text { toilet facility installed in both } \\
\text { Town A and Town B }\end{array}$ & $\begin{array}{l}\text { No targets have been set } \\
\text { Integration of services }\end{array}$ \\
\hline
\end{tabular}

* No examples of measurable targets were given for this area of service 


\section{Perceived barriers to achieving inclusive outcomes}

The final element of the survey asked why Partnership Boards had failed to achieve hoped-for goals. One frequent explanation was the difficulty of persuading both statutory and non-statutory organisations to engage with inclusive Board processes. Evidence of this can be seen in the low participation rates of certain organisations shown in table 1 - the practical consequences of which were far-reaching. For example, Boards reported being unable to improve access to public transport for people with learning disabilities because bus services were run by private companies. Similarly, they reported being powerless to prevent cuts in further education (FE) for people with learning disabilities because these were a result of national reductions in FE funding. Frustratingly, a range of statutory services - including leisure, job centres and Primary Care Trusts - simply did not engage with Partnership Boards.

This 'refusal to engage' undermined the ability of many Boards to achieve desired strategic-level change. It also underlined their inability to function as strategic bodies without having either direct control of budgets or the statutory powers to require other organisations to engage. Perhaps as a consequence, when asked what could be done to make Boards more effective, the most common response were calls for greater power and authority, as in "More formal authority so we have power over budgets" or "To have clear decision making powers, rather than just ad hoc consultative function".

\section{Positive engagement for inclusive outcomes}

Despite the many reported difficulties with Partnership Board processes and outcomes, there was evidence that a few Boards were succeeding in both adopting inclusive processes and directing strategic change within local services in order to support inclusive outcomes for all:

We do believe our Board works effectively and we are recognised both locally as being key to all decision making processes and nationally as a Board that is working well.

The effectiveness of such Boards appeared to rest on a number of factors, most of which were highly dependent on individuals and therefore hard to mandate. 
Firstly, effective Boards had highly committed members, who understood that achieving strategic change involved not only attending meetings but also 'the whole Board taking on a share of the work in between meetings'. Secondly, the make-up of Board members was important. Members with learning disabilities and family carers were more effective if they were linked with self-advocacy or service-user and carer organisations rather than co-opted on an individual basis, as this meant they were in a position to consult and represent the wider population rather than only able to voice personal opinions. Members representing statutory organisations needed to be both sufficiently senior to facilitate the transmission of Board decisions into their organisational decision-making processes and have sufficient commitment to inclusive policy processes for 'commissioning bodies [to accept] that the Board was the authoritative multi-agency vehicle for decision-making'. Furthermore, involvement from Elected Members from the Council and non-executive members of the PCT' was important because it gave Partnership Boards a direct link with the most senior level of political decision-making within social care and health.

Finally, because the realisation of Partnerships Boards as effective strategic bodies requires other organisations to loosen their grip on power and acknowledge implicitly or explicitly - the value of inclusive practices within policy-making processes, Boards needed a degree of determination and dogged persistence in order to reach this goal:

The Board is now, after many months of hard work, recognised as the strategic reference group for learning disability services. No decisions are made about services without full consultation with the Board, and with people who use services.

Some Boards had been fortunate in bringing together the optimal balance of individuals to succeed in gaining recognition from statutory agencies, maintaining the active inclusion of people with learning disabilities during Board meetings and focussing on ensuring inclusive outcomes for the wider population of people with learning disabilities. However, examples of Boards which struggled to achieve these competing goals outweighed those which had achieved such success. 


\section{Conclusion}

There was encouraging evidence, albeit from a few Boards, that effective practice at local level can result in both the inclusion of people with learning disabilities in policy processes and real strategic change. This finding echoes those of self-advocacy organisations which have promoted inclusion in policy development (DeardenPhillips \& Fountain, 2005) and regional organisations which have sought to improve the effectiveness of Partnership Boards (North West Training and Development Team, 2007). However, this study also suggests that the majority of Boards are not achieving this level of inclusion in either their processes or their outcomes.

Whilst a major barrier to Partnership Boards affecting strategic change is their lack of statutory powers and the subsequent limited engagement of statutory agencies, other factors were also apparent. There was evidence that many Boards are inward-facing. Spending time to make meetings inclusive is important, but continually focussing on matters of process and losing sight of wider outcomes is problematic.

It was concerning that some groups of people with learning disabilities, and certain topics of debate, risked exclusion from Partnership Boards. People with profound and multiple disabilities, who cannot speak for themselves; people from ethnic minority communities, who were outnumbered by the white majority; and those affected by issues which do not fit easily with Valuing People principles of rights, independence, choice and inclusion - in particular, adult safeguarding - may all find that their perspectives are excluded Partnership Boards.

Despite the accumulative evidence, including this study, pointing to a relative lack of effectiveness of many Partnership Boards as local strategic bodies, those responsible for policy at national level have continued to insist that Boards should play a key role in transforming services for people with learning disability. Writing in the foreword of Valuing People Now (Department of Health, 2009), the National Director for Learning Disabilities declared that: 
I see partnership boards as being central to the strategic planning, commissioning, delivery and performance management of all services as they relate to learning disability in every local area. (Department of Health, 2009, p. 6: emphasis in original)

When considered on the basis of current evidence, this determination to make Partnership Boards the mainstay of learning disability policy implementation appears perverse, not least because no plans have been put forward to give Boards a stronger statutory footing. However, the resolve to 'carry on regardless' can be understood if one views Partnership Boards as fulfilling an important symbolic role as emblems of inclusivity and empowerment for people with learning disabilities. Nevertheless, at a time when local authorities are making deep cuts to social care budgets, there is an acute need for Boards to justify their existence by being more than merely symbolic entities. They must fight to attain and maintain their rightful role as inclusive bodies with meaningful oversight of local services.

Some Boards may be in danger of recreating the same kinds of hierarchies which exist in wider society - one which favours the most able and articulate. More must be done to ensure that inclusion means inclusion for all. This may mean accepting that, whilst there is an important principle to be maintained in ensuring the direct involvement of people with learning disabilities in strategic planning, such inclusion is not necessarily sufficient to ensure change or prevent budget cuts. Those who place too much emphasis on Partnership Boards as a locus of inclusion may risk creating a situation in which they win the battle (for inclusive Boards) but lose the war (for an inclusive society). This is not an automatic conjunction: the best Partnership Boards demonstrated that inclusive processes and positive strategic outcomes are not mutually exclusive. However, tensions often remain between inclusion within and outcomes from Partnership Board processes. The optimal balance between inclusion and outcomes is a matter for local stakeholders to determine, but the challenge for many Partnership Boards is to ensure that their conception of inclusion shifts from simply focussing inwards on the small number of people with learning disabilities who attend Board meetings to securing the outcomes which will mean greater inclusion for all. 


\section{References}

Abbott, S \& McConkey, R (2006) The barriers to social inclusion as perceived by people with learning disabilities. Journal of Learning Disabilities 10 (3) 275287

Beyer, S, Grove, B, Schneider, J, Simons, K, Williams, V, Heyman, A, Swift, P \& Krijnen-Kemp, E (2004) Working lives: The role of day centres in supporting people with learning disabilities into employment. Department for Work and Pensions, Research Report No 203. Crown Copyright

Clement, T \& Bigby, C (2009) Breaking Out of a Distinct Social Space: Reflections on Supporting Community Participation for People with Severe and Profound Learning Disability Journal of Applied Research in Learning Disability 22 (3) 264-275

Dearden-Phillips, C \& Fountain, R (2005) Real Power? An examination of the involvement of people with learning difficulties in strategic service development in Cambridgeshire British Journal of Learning Disabilities 33

(4) 200-204

Department of Health (1971) Better Services for the Mentally Handicapped $[\mathrm{Cm}$ 4683] London: HMSO

Department of Health (2001) Valuing People: A New Strategy for Learning Disability for the $21^{\text {st }}$ Century [Cm 5086] London: The Stationery Office

Department of Health (2001a) HSC2001/016: LAC(2001)23 Valuing People: A New Strategy for Learning Disability for the $21^{\text {st }}$ Century: Implementation. London: Department of Health

Department of Health (2002) Keys to Partnership: working together to make a difference in people's lives (summary version). London: Department of Health

Department of Health (2007) Local Authority Social Services Letter $\operatorname{LASSL}(D H)(2007) 2$ London: Department of Health, 10 ${ }^{\text {th }}$ December 2007

Department of Health (2009) Valuing People Now: A New Three-Year Strategy for people with learning disabilities London: Department of Health

Forrester-Jones R, Carpenter J, Coolen-Schrijner P, Cambridge P, Tate A, Beecham J, Hallam A, Knapp M \& Wooff, D (2006) The Social Networks of People with Learning Disability Living in the Community 12 Years after Resettlement from Long-Stay Hospitals Journal of Applied Research in Learning Disability 19 (4) 285-295

Fyson, R, McBride, G \& Myers, B (2004) Progress on Participation? Self-Advocate Involvement in Learning Disability Partnership Boards Tizard Learning Disability Review 9 (3) 27-36

Fyson, R \& Ward, L (2004) Making Valuing People Work: Strategies for change in learning disability services. Bristol: Policy Press.

Hall, E (2004) Social geographies of learning disability: narratives of exclusion and inclusion Area 36 (3) 298-306

Hamlin, A \& Oakes, P (2008) Reflections on Deinstitutionalization in the United Kingdom Journal of Policy \& Practice in Learning Disability 5 (1) 47-55 
Hatton, C (2004) Improving Services for People with Learning Disabilities from Minority Ethnic Groups: Results of a National Survey of Partnership Boards. VPST http://valuingpeople.gov.uk/dynamic/valuingpeople90.jsp

Learning Disability Task Force (2003) Making Things Happen: First annual report of the Learning Disability Task Force London: Learning Disability Task Force

Learning Disability Task Force (2004) Rights, Independence Choice and Inclusion: the 2nd Learning Disabilities Task Force report London: Learning Disability Task Force

Learning Disability Task Force (2005) Learning Disability Task Force: Annual report 2004 - Challenging, listening, helping to improve lives London: Learning Disability Task Force

Learning Disability Task Force (2007) The Learning Disability Task Force Annual Report 2006-07: Could do better London: Learning Disability Task Force

Mencap (2003) Out of sight, out of mind: A report on the limited public profile of Learning Disability Partnership Boards. London: Mencap

Mencap (2004) PMLD Network - Partnership Board Survey 2004 London: Mencap

North West Training and Development Team Regional Taskforce (2007) Making our Partnership Board work. Accrington: North West Training and Development Team

Redley, M \& Weinberg, D (2007) Learning disability and the limits of liberal citizenship: interactional impediments to political empowerment Sociology of Health \& Illness 29 (5) 767-786

Riddington, C, Mansell, J \& Beadle-Brown, J (2008) Are partnership boards really valuing people? Disability \& Society 23 (6) 649-665

Scott, J (2003) Partnership Boards - Making Them Work Journal of Integrated Care 11 (3) $5-8$

Speaking Up (2007) How well are Partnership Boards hearing the voices of People with Learning Difficulties and Family Carers? Care Services Improvement Partnership \& Valuing People Support Team

Whitworth, J. (2002) Valuing People in Partnership: a survey of local authorities on the introduction of Learning Disability Partnership Boards. Research Briefing 15 London: Local Government Association 